\title{
THE PREVALENCE OF PATHOGENIC FORMS OF LEPTOSPIRA IN NATURAL POPULATIONS OF SMALL WILD MAMMALS IN SERBIA
}

\author{
Jelena BlagoJeVIĆ ${ }^{*}$, Milanko ŠEKLER ${ }^{2}$, Marija RAJIČIĆ ${ }^{1}$, Branka PEJIĆ ${ }^{1}$, \\ Ivana BuDINSKI ${ }^{1}$, Vladimir M. JOVANOVIĆ ${ }^{1}$, Tanja ADNAĐEVIĆ ${ }^{1}$, Dejan VIDANOVIĆ ${ }^{2}$, \\ Kazimir MATOVIĆ ${ }^{2}$ and Mladen VuJOŠEVIĆ ${ }^{1}$ \\ ${ }^{1}$ University of Belgrade, Institute for Biological Research 'Siniša Stanković', \\ Bulevar despota Stefana 142, Belgrade 11060, Serbia; \\ ${ }^{2}$ Veterinary Specialized Institute 'Kraljevo', Kraljevo, Serbia
}

(Received 21 March 2019; accepted 31 July 2019)

The greatest epidemiological significance of leptospirosis in Europe comes from the fact that it is the most widespread zoonosis in the world. However, epizootiological data, especially information on maintenance hosts such as small wild mammals, are largely missing. To fill this gap in data in Serbia, we used RTPCR for the detection of pathogenic Leptospira species and analysed 107 animals belonging to six species of small wild mammals (Apodemus agrarius, Apodemus flavicollis, Microtus arvalis, Myodes glareolus, Microtus subterraneus and Sorex araneus) collected from two localities. The animals from the first locality that was situated in a tourist area, were collected for four consecutive years (2014-2017). We found persistent incidence of infection from year to year ranging from $6.67 \%$ to $78.57 \%$. The average frequency of infected animals was $33.3 \%$ with the highest frequency in 2014, the year characterised by a very high number of flooding days. All animals proved to be infected with pathogenic Leptospira species that were collected from the second locality situated in an agricultural area in a single year, 2014. The findings show a variable but constant presence of pathogenic Leptospi$r a$ species in populations of small wild mammals in the studied areas, which indicates the need for constant monitoring.

Key words: Leptospira spp., small wild mammals, leptospirosis, RT-PCR

Zoonoses are infections naturally transmissible from vertebrate animals to humans. The transmission may occur through direct contact with animals or indirectly, e.g. through the consumption of contaminated food products. Although leptospirosis is recognised as the most widespread zoonosis in the world, its incidence is still increasing (Bharti et al., 2003). Pathogenic spirochetes of the genus Leptospira have an impact on a wide variety of mammalian species, includ-

*Corresponding author; E-mail: jelena.blagojevic@ibiss.bg.ac.rs;

Phone: 00381 (11) 2078-331; Fax: 00381 (11) 2764-422 
ing livestock, domestic pets and humans. Costa et al. (2015) estimated that there are more than a million cases of leptospirosis with almost 60,000 deaths in the human population worldwide.

At the present time, a classification based on DNA homology recognises 20 species of the Leptospira genus with nine pathogenic ones: Leptospira alexanderi, L. alstonii, L. borgpetersenii, L. interrogans, L. kmetyi, L. kirschneri, L. noguchii, L. santarosai and $L$. weillii (Picardeau, 2013). Furthermore, the genus is categorised into 25 serogroups and more than 300 serovars (Picardeau, 2013). PCR methods are used most commonly instead of the technically more demanding DNA-DNA hybridisation (Ahmed et al., 2012a,b). The species with a global distribution (L. interrogans, L. borgpetersenii and L. kirschneri) are genetically more diverse and the majority of pathogenic serovars belong to them. The broad geographical distribution includes both rural and urban areas of tropical, subtropical and temperate regions. The spread of some pathogenic Leptospira species is associated with the expansion of the maintenance host area. It is assumed that the expansion of the brown rat, Rattus norvegicus, introduced L. interrogans serovar Icterohaemorrhagiae to Western Europe during the 18th century (Alston and Broom, 1958). By now, the risk of disease outbreaks in the developed countries has shifted from occupational exposures to different recreational exposures (Richard and Oppliger, 2015), especially the ones connected with water. In some regions, though, the dynamics of the environmentally transmitted Leptospira pathogens have not been well characterised yet. The environmental factors that influence their abundance and distribution, and therefore the risk of infection, are still poorly understood.

Pathogenic Leptospira colonises the kidneys and persists as a chronic infection of the renal tubules in animals designated as maintenance hosts (Gamage et al., 2011; Perez et al., 2011; Calderon et al., 2014; Andersen-Ranberg et al., 2016). The infection is usually transferred from animal to animal by direct contact. Via urine, Leptospira has been distributed into the environment where it survives for a period that ranges from a few hours to several months depending on the species, serovar and the characteristics of the environment (Hellstrom and Marshall, 1978; Khairani-Bejo et al., 2004; Trueba et al., 2004; Thibeaux et al., 2017). The most important maintenance hosts are small wild mammals, which may transfer infection to other wild and domestic animals, pets, and humans that are typical accidental hosts (Levett, 2001). Although major leptospirosis outbreaks occur in subtropical and tropical regions, in temperate areas leptospires usually produce sporadic epidemics (Watt, 2010). Infections in humans may occur after contact with moist soil, vegetation, flood or freshwater contaminated by the urine of infected animals.

There is no data on Leptospira presence in maintenance hosts in Serbia, so the goal of this study was to determine the prevalence of Leptospira infection in small wild mammals in human settlements surrounded by wildlife. 


\section{Materials and methods}

Animals were collected from two localities. The first one was in the surrounding of Vlasina lake $\left(42.736060^{\circ} \mathrm{N}, 22.332332^{\circ} \mathrm{E}\right)$ in a protected area (landscape of outstanding features), a well-known tourist destination in the southeast of Serbia. The second locality was an agricultural village, Misača $\left(44.360833^{\circ} \mathrm{N}\right.$, $20.544722^{\circ} \mathrm{E}$ ) in central Serbia. The capturing was carried out by using Longworth traps provided with hay and food. Eighty-one animals were collected from the locality Vlasina during four consecutive years (October 2014, June 2015 and 2016, July 2017), while in the locality Misača 26 animals were collected in June 2014. In the locality Vlasina, the animals were caught on meadows and in forests located in the vicinity of a lake. In the locality Misača, the traps were set up along a small stream flowing through the village. Both locations were characterised by a high level of soil moisture due to being close to a water surface. There were multiple floods that affected the southeast of Europe (ESRI, 2015) in May 2014. According to the report of the Hydrometeorological Service of Serbia, the year 2014 had an annual rainfall 93\% higher than the average (http://www. hidmet.gov.rs/podaci/meteorologija/eng/2014.pdf) and was the second warmest year on record since 1951.

The collected animals were transported to the laboratory and euthanised with an overdose of anaesthetic (diethyl ether, Carlo Erba), while the biometric data of all animals was noted. Tissue samples were extracted and stored at $-20{ }^{\circ} \mathrm{C}$. All procedures performed on animals were approved by the Ethical Committee for the Use of Laboratory Animals of the Institute for Biological Research 'Siniša Stanković', and done in accordance with the legal and ethical guidelines as indicated in Directive 2010/63/EU of the European Parliament and the Council of 22nd September 2010.

Kidney samples, weighing approximately $20 \mathrm{mg}$, were cut into small pieces each with a sterile scalpel and then homogenised. Genomic DNA was extracted by using Quick-gDNA Midi Prep Kit (Zymo-Research, CA, USA) in accordance with the manufacturer's procedure, following overnight digestion with proteinase $\mathrm{K}$ at $55^{\circ} \mathrm{C}$. For all samples, the quality and quantity of the extracted DNA samples were determined with a spectrophotometer.

We applied RT-PCR assay using a TaqMan probe and primers designed to target lipL32, which is present only in pathogenic Leptospira species, developed by Stoddard et al. (2009). The amplification protocol on the AriaMx Real-Time PCR system (Agilent Technologies, CA, USA) consisted of $95^{\circ} \mathrm{C}$ for $3 \mathrm{~min}$, followed by 45 cycles of amplification $\left(95^{\circ} \mathrm{C}\right.$ for $15 \mathrm{~s}$ and $60^{\circ} \mathrm{C}$ for $\left.30 \mathrm{~s}\right)$. The samples with a $\mathrm{Ct}$ value below 37 were considered to be positive.

Statistical comparisons of frequencies of infected animals between successive years in the locality Vlasina were done by the chi-squared test using Statistica 7 software (StatSoft, Inc., 2004). 


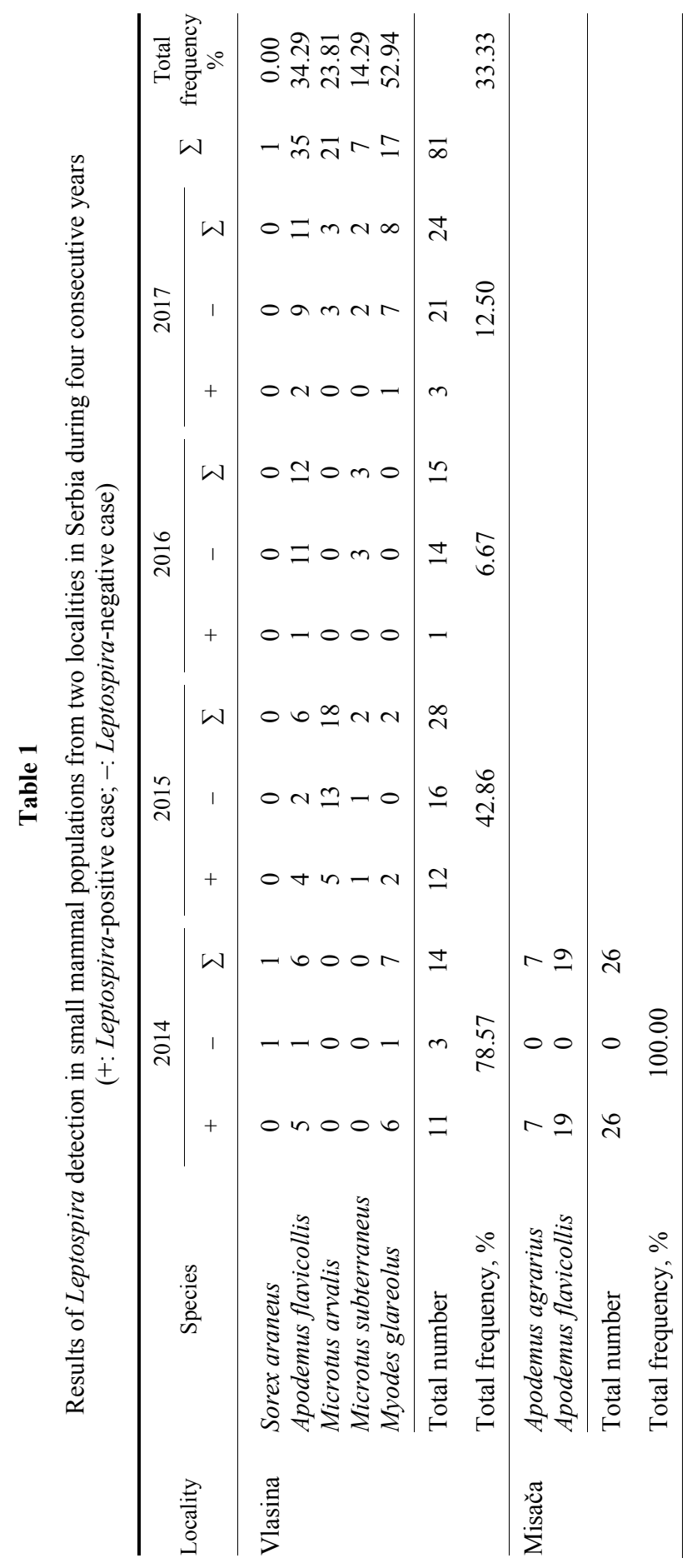




\section{Results}

A total of 107 animals belonging to six species were collected, including 54 yellow-necked mice (Apodemus flavicollis), 21 common voles (Microtus arvalis), 17 bank voles (Myodes glareolus), seven striped field mice (Apodemus agrarius), seven European pine voles (Microtus subterraneus), and one common shrew (Sorex araneus) (Table 1). The diversity of species was higher in the locality Vlasina than in the locality Misača. Four rodent species and one insectivore were caught in the locality Vlasina, while in the locality Misača only two Apodemus species (A. flavicollis and A. agrarius) were present.

The number of tested animals varied from 14 animals in 2014 to 28 in 2015 during the four years of the study in the locality Vlasina. The frequencies of infected animals ranged from $6.67 \%$ to $78.57 \%$ (Table 1). Differences in frequency of infected samples were statistically significant between years 2014/ $2015\left(\mathrm{X}^{2}=4.81 ; \mathrm{P}<0.001\right)$ and $2015 / 2016\left(\mathrm{X}^{2}=6.07 ; \mathrm{P}=0.014\right)$, but insignificant between 2016/2017 $\left(X^{2}=0.34 ; P=0.559\right)$. During the four successive years the most frequent species at Vlasina was A. flavicollis (43.21\%), followed by $M$. arvalis $(25.93 \%)$ and $M$. glareolus $(20.99 \%)$.

The highest prevalence of pathogenic Leptospira species was found in $M$. glareolus (52.94\%) and A. flavicollis (34.29\%) in the locality Vlasina. In that area, the highest level of infection (78.57\%) was detected in 2014.

In the locality Misača all animals belonging to two species (A. flavicollis and $A$. agrarius) were infected with pathogenic Leptospira species.

\section{Discussion}

Small wild mammals are important reservoir hosts for different zoonotic pathogens which can be transferred to humans and domestic animals. Epizootiological data in Europe are scarce despite the great epidemiological significance of leptospirosis (ECDPC, 2016). Only a few surveys in domestic animals were conducted in Serbia in the last decade (Manić et al., 2014; Obrenović et al., 2014; Vojinović et al., 2015), despite the fact that leptospirosis infection is still common in humans (Svirčev et al., 2009; ECDPC, 2016). A high seroprevalence (26.7\%) of Leptospira-specific antibodies was found in domestic cats in a previous study in the Belgrade region (Obrenović et al., 2014). Lower seroprevalence was reported in dogs (14.0\%) and in horses (6.3\%) (Vojinović et al., 2009). Small wild mammals are considered to be the maintenance hosts of Leptospira, therefore the more frequent effective contacts of cats with these primary reservoirs of bacteria result in higher incidence of infection in cats compared to dogs and horses. Until now, there was no survey in Serbia in populations of small wild mammals. The average frequency of small wild mammals found to be infected with pathogenic Leptospira species in the present study (33.3\%) is comparable to 
values published from the neighbouring countries. The seroprevalence of Leptospira species was reported to be $29.9 \%$ (Stritof Majetić et al., 2014) and $46 \%$ (Tadin et al., 2012) in Croatia, while a $18.3 \%$ prevalence rate was detected by PCR in Hungary (Kurucz et al., 2018). A much lower frequency (based on RTPCR) of infected small wild mammals (5.9\%) was found on three different sites in Germany (Obiegala et al., 2016). Temperature is one of the factors limiting the survival of leptospires. Therefore, the disease is seasonal in temperate regions, with the peak incidence occurring in the summer or autumn. Human cases of leptospirosis are rising from north to south of Europe (ECDPC, 2016). This can explain why the frequency of infected small wild mammals is much lower in Germany than in the South European populations. Besides increasing the average temperature, global warming affects the incidence of floods that could potentially lead to the rise of Leptospira spreading in the future.

A further important factor in the maintenance and spread of Leptospira is moisture. This is illustrated by the extremely high frequency of infected animals in 2014 in both localities, with all animals being infected in the locality Misača. After the outbreak in 2014, probably caused by floods, the frequency of infected animals in Vlasina significantly decreased in the subsequent years. Contrary to our findings, a survey examining 60 small wild mammals using nested-PCR method in Poland showed that the number of infected animals did not correlate with flooding (Wójcik-Fatla et al., 2013). It is possible that the size of the flooded area can directly affect the spread and intensity of infection, or can indirectly influence the population dynamics of small mammals. The urbanisation of natural areas can have an effect on both humidity and temperature. For instance, based on the seasonal incidence of Leptospira among small wild mammals in Barcelona, Millán et al. (2017) suggested that people could face a higher risk of infection with Leptospira in Mediterranean periurban areas.

The most common method to diagnose leptospirosis is the use of serological tests: microscopic agglutination test (MAT) and the detection of immunoglobulin M - IgM (ELISA) antibodies (Budihal and Perwez, 2014). In addition, immunoglobulin $\mathrm{G}$ - IgG specific ELISA kits are also commercially available for the detection of antibodies against Leptospira. Molecular techniques (PCR, RT-PCR) are capable of detecting the presence of leptospiral DNA even if it is found in a small number of copies. The unequal sensitivity of the applied laboratory methods could produce differences in the level of Leptospira detection. For instance, in a sample of 103 human patients with meningitis of unknown cause Romero et al. (1998) showed that the detection of Leptospira was highly dependent on the applied method. They detected $3.9 \%$ positive cases by ELISA, $8.7 \%$ by MAT and as many as $39.1 \%$ by PCR. This indicates that the prevalence of leptospirosis could be much higher in the natural populations of small wild mammals than it was obtained before the application of molecular techniques. 
The sensitivity of the RT-PCR method applied in this analysis allowed a more precise estimation of Leptosipra infection in the maintenance hosts.

Today, the incidences of recreational exposure are increasing, while the incidences of occupational exposure are decreasing in the developed countries (Richard and Oppliger, 2015). All freshwater sport activities potentially increase the number of human infections in places with the permanent persistence of Leptospira. Our results show a variable number of infected animals but the constant presence of pathogenic Leptospira in the populations of small wild mammals in the tourist locality Vlasina which indicates the need for constant monitoring. According to our findings, this kind of monitoring should also include agricultural regions.

\section{Acknowledgements}

The study was supported by the Ministry of Education, Science and Technological Development of Serbia, Grant No. 173003. The authors thank the Tourist Organization of the Municipality of Surdulica for their support and help during the field research in Vlasina.

\section{References}

Ahmed, A., Grobusch, M. P., Klatser, P. and Hartskeerl, R. A. (2012a): Molecular approaches in the detection and characterization of Leptospira. J. Bacteriol. Parasitol. 3, 133 http://dx.doi.org/10.4172/2155-9597.1000133

Ahmed, A., Klaasen, H. L. B. M., van der Veen, M., van der Linden, H., Goris, M. G. A. and Hartskeerl, R. A. (2012b): Evaluation of real-time PCR and culturing for the detection of leptospires in canine samples. Adv. Microbiol. 2, 162-170.

Alston, J. M. and Broom, J. C. (1958): Leptospirosis in man and animals. E. \& S. Livingstone, Edinburgh, UK.

Andersen-Ranberg, E. U., Pipper, C. and Jensen, P. M. (2016): Global patterns of Leptospira prevalence in vertebrate reservoir hosts. J. Wildl. Dis. 52, 468-477.

Bharti, A. R., Nally, J. E., Ricaldi, J. N., Matthias, M. A., Diaz, M. M., Lovett, M. A., Levett, P. N., Gilman, R. H., Williq, M. R., Gotuzzo, E., Vinetz, J. M., Peru-United States Leptospirosis Consortium (2003): Leptospirosis: a zoonotic disease of global importance. Lancet Infect. Dis. 3, 757-771.

Budihal, S. V. and Perwez, K. (2014): Leptospirosis diagnosis: Competency of various laboratory tests. J. Clin. Diagn. Res. 8, 199-202.

Calderon, A., Rodriguez, V., Mattar, S. and Arrieta, G. (2014): Leptospirosis in pigs, dogs, rodents, humans, and water in an area of the Colombian tropics. Trop. Anim. Health Prod. 46, 427-432.

Costa, F., Hagan, J. E., Calcagno, J., Kane, M., Torgerson, P., Martinez-Silveira, M. S., Stein, C., Abela-Ridder, B. and Ko, A. I. (2015): Global morbidity and mortality of leptospirosis: A systematic review. PLoS Negl. Trop. Dis. 9, e0003898.

ESRI (2015): ESRI Disaster Response Program. Southeast Europe Flooding California: ESRI; 2014 [cited 2015 November 6]. Available from: http://www.esri.com/services/disasterresponse/ floods/southeasteuropeflooding.

ECDPC (2016): European Centre for Disease Prevention and Control. Annual Epidemiological Report 2016 - Leptospirosis. [Internet]. Stockholm: ECDPC, 2016 [cited 2019 January 
10]. Available from: http://ecdc.europa.eu/en/healthtopics/leptospirosis/Pages/Annualepidemiologicalreport2016.aspx

Gamage, C. D., Koizumi, N., Muto, M., Nwafor-Okoli, C., Kurukurusuriya, S., Rajapakse, J. R., Kularatne, S. A., Kanda, K., Lee, R. B., Obayashi, Y., Watanabe, H. and Tamashiro, H. (2011): Prevalence and carrier status of leptospirosis in smallholder dairy cattle and peridomestic rodents in Kandy, Sri Lanka. Vector Borne Zoonotic Dis. 11, 1041-1047.

Hellstrom, J. S. and Marshall, R. B. (1978): Survival of Leptospira interrogans serovar pomona in an acidic soil under simulated New Zealand field conditions. Res. Vet. Sci. 25, $29-33$.

Khairani-Bejo, S., Bahaman, A. R., Zamri-Saad, M. and Mutalib, A. R. (2004): The survival of Leptospira interrogans in the Malaysian environment. J. Anim. Vet. Adv. 3, 123-129.

Kurucz, K., Madai, M., Bali, D., Hederics, D., Horváth, G., Kemenesi, G. and Jakab, F. (2018): Parallel survey of two widespread renal syndrome-causing zoonoses: Leptospira spp. and Hantavirus in urban environment, Hungary. Vector Borne Zoonotic Dis. 18, 200-205.

Levett, P. N. (2001): Leptospirosis. Clin. Microbiol. Rev. 14, 296-326.

Manić, M., Prokić, N., Gojković, K., Đorić, G., Vasić, A., Marić, J., Vojinović, D. and Đuričić, B. (2014): Seroprevalence of some infectious diseases in stray dogs in the wider territory of Leskovac. Arh. vet. med. 7, 19-27.

Millán, J., Cevidanes, A., Chirife, A. D., Candela, M. G. and León-Vizcaíno, L. (2017): Risk factors of Leptospira infection in Mediterranean periurban micromammals. Zoonoses Public Hlth 65, e79-e85. doi:10.1111/zph.12411

Obiegala, A., Woll, D., Karnath, C., Silaghi, C., Schex, S., Eßbauer, S. and Pfeffer, M. (2016): Prevalence and genotype allocation of pathogenic Leptospira species in small mammals from various habitat types in Germany. PLoS Negl. Trop. Dis. 10, e0004501. doi:10.1371/journal.pntd.0004501

Obrenović, S., Radojčić, S., Stević, N., Bogunović, D., Vukanjac, S. and Valčić, M. (2014): Seroprevalence of cat leptospirosis in Belgrade (Serbia). Acta Vet. Beograd 64, 510-518.

Perez, J., Brescia, F., Becam, J., Mauron, C. and Goarant, C. (2011): Rodent abundance dynamics and leptospirosis carriage in an area of hyper-endemicity in New Caledonia. PLoS Negl. Trop. Dis. 5, e1361.

Picardeau, M. (2013): Diagnosis and epidemiology of leptospirosis. Med. Mal. Infect. 43, 1-9.

Richard, S. and Oppliger, A. (2015): Zoonotic occupational diseases in forestry workers - Lyme borreliosis, tularemia and leptospirosis in Europe. Ann. Agric. Environ. Med. 22, 43-50.

Romero, E. C., Billerbeck, A. E. C., Lando, V. S., Camargo, E. D., Souza, C. C. and Yasuda, P. H. (1998): Detection of leptospira DNA in patients with aseptic meningitis by PCR. J. Clin. Microbiol. 36, 1453-1455.

StatSoft, Inc. (2004): STATISTICA (data analysis software system), version 7. www.statsoft.com.

Stoddard, R. A., Gee, J. E., Wilkins, P. P., McCaustland, K. and Hoffmaster, A. R. (2009): Detection of pathogenic Leptospira spp. through TaqMan polymerase chain reaction targeting the LipL32 gene. Diagn. Microbiol. Infect. Dis. 64, 247-255.

Stritof Majetić, Z., Galloway, R., Ruzić Sabljić, E., Milas, Z., Mojcec Perko, V., Habus, J., Margaletić, J., Pernar, R. and Turk, N. (2014): Epizootiological survey of small mammals as Leptospira spp. reservoirs in Eastern Croatia. Acta Trop. 131, 111-116.

Svirčev, Z., Marković, S. B., Vukadinov, J., Stefan-Mikić, S., Ruzić, M., Doder, R., Fabri, M., Canak, G., Turkulov, V., Stojanović, D. B. and Draganić, M. (2009): Leptospirosis distribution related to freshwater habitats in the Vojvodina region (Republic of Serbia). Sci. China Ser. C 52, 965-971.

Tadin, A., Turk, N., Korva, M., Margaletić, J., Beck, R., Vucelja, M., Habuš, J., Svoboda, P., Zupanc, T. A., Henttonen, H. and Markotić, A. (2012): Multiple co-infections of rodents with hantaviruses, Leptospira, and Babesia in Croatia. Vector Borne Zoonotic Dis. 12, 388-392. 
Thibeaux, R., Geroult, S., Benezech, C., Chabaud, S., Soupé-Gilbert, M.-E., Girault, D., Bierque, E. and Goarant, C. (2017): Seeking the environmental source of leptospirosis reveals durable bacterial viability in river soils. PLoS Negl. Trop. Dis. 11, e0005414.

Trueba, G., Zapata, S., Madrid, K., Cullen, P. and Haake, D. (2004): Cell aggregation: A mechanism of pathogenic Leptospira to survive in fresh water. Int. Microbiol. 7, 35-40.

Vojinović, D., Žutić, J. and Stanojević, S. (2009): Seroprevalence of leptospirosis in horses in the territory of Belgrade during the period from 1998 to 2008. Vet. Glas. 63, 163-169.

Vojinović, D., Bogićević, N., Vasić, A., Manić, M., Elezović Radovanović, M., Rogožarski, D., Marić, J. and Valčar, M. (2015): Seroepidemiological survey of leptospiral infection in stray dogs in Serbia. Turk. J. Vet. Anim. Sci. 39, 719-723.

Watt, G. (2010): Leptospirosis. Oxford University Press Inc., New York. pp. 874-879.

Wójcik-Fatla, A., Zając, V., Sroka, J., Piskorski, M., Cisak, E., Sawczyn, A. and Dutkiewicz, J. (2013): A small scale survey of Leptospira in mammals from eastern Poland. Ann. Agr. Env. Med. 120, 705-707. 